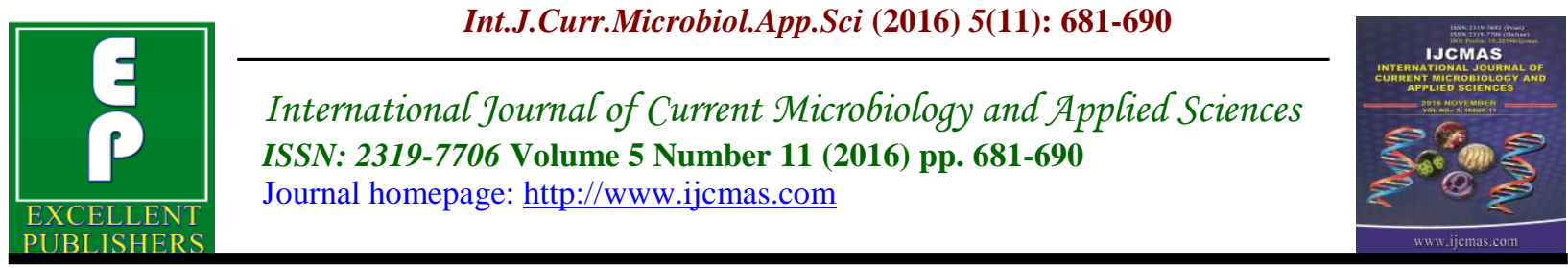

Original Research Article

http://dx.doi.org/10.20546/ijcmas.2016.511.079

\title{
Characterization of Lipase from Wild (LPF-5) and Mutant (HN1) Strain of Aspergillus niger
}

\author{
Arun Kumar Sharma ${ }^{1}$, Vinay Sharma ${ }^{1 *}$ and Jyoti Saxena ${ }^{2}$ \\ ${ }^{1}$ Department of Bioscience and Biotechnology, Banasthali University, Rajasthan, India \\ ${ }^{2}$ Department of Biochemical Engineering, Bipin Tripathi Kumaon Institute of Technology, \\ Dwarahat, Uttrakhand, India \\ *Corresponding author
}

Ke y w ords

A. niger, mutant strain (HN1), wild strain (LPF-5), temperature, $\mathrm{pH}$, metal ions, methanol, characterization.

\section{Article Info}

Accepted:

26 October 2016

Available Online:

10 November 2016

\section{A B S T R A C T}

Lipase is one of the most imperative industrial enzymes and has a variety of applications in various industries. In the present study, lipases obtained by submerged cultivation of wild (LPF-5) and mutant (HN1) strain of A. niger were used and compared for characterization study. Activity and stability of partially purified lipase was determined under different $\mathrm{pH}$, temperature, organic solvents and metal ions. The lipase showed highest activity and stability at $\mathrm{pH} 7.0$ and temperature $35{ }^{\circ} \mathrm{C}$ for LPF- 5 and $30{ }^{\circ} \mathrm{C}$ for $\mathrm{HN} 1$ strain. The lipases retained high activity over ranges of temperature $\left(25-50{ }^{\circ} \mathrm{C}\right)$ and $\mathrm{pH}$ (4.0-7.5). Lipase was enhanced by methanol and acetone, while slightly inhibited by butanol $(10 \% \mathrm{v} / \mathrm{v})$. $\mathrm{Ca}^{2+}$ appeared to be the excellent inducer of lipase activity. Lipase also showed stability in presence of the other metal ions $\left(\mathrm{Na}^{+}, \mathrm{Ba}^{2+}, \mathrm{Mg}^{2+}, \mathrm{Cu}^{2+}, \mathrm{Fe}^{2+}\right.$ and $\left.\mathrm{Mn}^{2+}\right)$. The lipase of wild and mutant strain retained $10.58 \%$ and $14.60 \%$ of its activity when pre-incubated with $\mathrm{Hg}^{2+}$, indicating the inhibitory effect of $\mathrm{Hg}^{2+}$ on catalytic activity of lipase.

\section{Introduction}

Lipases (triacyl glycerol acylhydrolases, EC 3.1.1.3) belonging to the class Hydrolases catalyze hydrolysis of insoluble triacylglycerols (TAGs) to generate free fatty acids, mono and diacylglycerols and glycerol (Das et al., 2016). Lipases are found in both prokaryotes (bacteria and archaea) as well as in eukaryotes (animals, plants and fungi) (Cai-hong et al., 2008). The most broadly applied lipases are microbial due to their stability and chemical properties (Hasan et al., 2009). Although several microorganisms are recognized as potent producers of lipases (extracellular) including fungi, yeast and bacteria but fungal lipases are being used for diverse applications in biotechnological industries (Sharma and Kanwar, 2014). Extracellular secretion of lipases has been well documented for a variety of fungi (yeasts, zygomycetes and hyphomycetes). Filamentous fungi are preferred sources of lipases among the rest of the lipase producing microorganisms. The main producers of commercial lipases mainly are Rhizopus sp., Pencillium sp., Aspergillus sp., Mucor sp., Fusarium sp., Candida 
rugosa, Acremonium alcalophilum and Geotrichum candidum (Jayaprakash and Ebenezer, 2012).

Soil is one of the excellent sources for the isolation of novel lipase producing microorganisms as it gives nutrient rich environment to enable the high proliferation of microorganisms (Shukla and Desai, 2016). About 3000 enzymes are known today but only a certain enzymes are being used in various industries. These are mainly hydrolytic enzymes (secreted extracellularly), which are capable of degrading natural polymers such as cellulose, lipid, starch, proteins and pectin into simpler monomers (Sharma et al., 2015). Following carbohydrases and proteases, lipases are believed to be the third major group based on total sales volume (Ray, 2012). Lipases (and esterases) are capable of catalyzing three types of reactions. The biological action of lipases is reversible. They are capable of catalyzing hydrolysis in an aqueous environment and esterification in a micro aqueous environment, in which content of water is very low. According to the nature of chemical species which react with the ester, transesterification is classified into four subclasses: alcoholysis, acidolysis, interesterification and aminolysis (Sharma and Kanwar, 2014). Lipases found promising application in various industries such as detergent, agrochemical, paper, chemical processing, dairy, pharmaceuticals, oleochemical, cosmetics, polymer synthesis, synthesis of surfactants and personal care products (Ray, 2012).

Lipase characterization would determine its possible utilization in various environments and industries. The optimum $\mathrm{pH}$ for the fungal lipases was found to be in the range of 4.0 to 8.0 (Hasan et al., 2009). The majority of the fungi have optimum temperature between $25-30{ }^{\circ} \mathrm{C}$ for highest activity of lipase except for certain thermophilic fungi which have optimum temperature range of $45-75{ }^{\circ} \mathrm{C}$ (Sharma et al., 2011).

In view of the significance of lipase for numerous applications, we made an attempt to determine the stability of lipase (obtained from wild and mutant strain of $A$. niger) under different $\mathrm{pH}$, temperatures, organic solvents and metal ions.

\section{Materials and Methods}

\section{Production of lipase from Aspergillus niger}

Wild (LPF-5) and hyperproducer nitrous acid mutant strain (HN1) of A. niger were obtained from Department of Bioscience and Biotechnology, Banasthali University and utilized for lipase production in submerged fermentation. Spore suspensions were prepared from 7 days old slant culture of both the fungus and $1 \mathrm{~mL}$ of this was transferred in $250 \mathrm{~mL}$ Erlenmeyer flask containing $100 \mathrm{~mL}$ of production medium followed by incubation at $28^{\circ} \mathrm{C}, 160 \mathrm{rpm}$ for $42 \mathrm{~h}$. The composition of production medium $\left(\mathrm{g} \mathrm{L}^{-1}\right)$ is as follows: bacteriological peptone, 10; olive oil, $1 \% ; \mathrm{MgSO}_{4} .7 \mathrm{H}_{2} \mathrm{O}$, $0.6 ; \mathrm{KH}_{2} \mathrm{PO}_{4}, 1.0 ; \mathrm{NH}_{4} \mathrm{NO}_{3}, 1.0$ and $\mathrm{pH}$ was adjusted to 7.0. At the end of incubation, enzyme containing supernatant was recovered after filtration and centrifugation of culture broth.

\section{Lipase assay}

Lipase activity was determined by spectrophotometric technique (using $p$ nitrophenyl palmitate as substrate) (Winkler and Stuckmann, 1979). Upon completion of enzymatic reaction, the quantity of released yellow colour compound ( $p$-nitrophenol) 
was measured at $410 \mathrm{~nm}$ against a reagent blank using reference curve of $p$-nitrophenol (in the concentration range of $2-20 \mu \mathrm{g} \mathrm{mL}^{-1}$ of $p$-nitrophenol in $0.05 \mathrm{M}$ Tris $\mathrm{HCl}$ buffer, $\mathrm{pH}-8.0)$. One unit (U) of lipase activity was defined as micromole $(\mu \mathrm{M})$ of $p$ nitrophenol liberated by hydrolysis of $p$ nitrophenyl ester by one $\mathrm{mL}$ of soluble enzyme per minute at $35{ }^{\circ} \mathrm{C}$ under standard assay conditions.

\section{Partial purification of lipase enzyme}

Lipase produced by both the wild (A. niger LPF-5) and mutant (A. niger HN1) strain was partially purified by ammonium sulfate precipitation (Data is not shown here).

Characterization of partially purified lipase of wild (LPF-5) and mutant strain (HN1) of A. niger

The partially purified lipase preparation (obtained at $70 \% \quad\left(\mathrm{NH}_{4}\right)_{2} \mathrm{SO}_{4}$ saturation) from both the wild and mutant strain was then characterized to study the impact of $\mathrm{pH}$, temperature, organic solvents and metal ions on the stability and activity of the lipase.

\section{Impact of $\mathbf{p H}$ on the activity and stability of partially purified lipase}

To determine the $\mathrm{pH}$ optima, lipase activity was measured at various $\mathrm{pH}(4,5,5.5,6.0$, $6.5,7.0,7.5,8.0$ and 9.0). The $\mathrm{pH}$ of the reaction mixture was adjusted using buffers of different $\mathrm{pH}$. These buffer solutions (20 $\mathrm{mM}$ ) include sodium acetate buffer (4 and $5)$, sodium phosphate buffer (6 and 7), Tris$\mathrm{HCl}$ buffer (8 and 9) and sodium bicarbonate buffer (10 and 11) (Sarkar and Laha, 2013).

pH stability was determined by preincubation of lipase preparation with the buffers of above mentioned $\mathrm{pH}$. The partially purified enzyme and respective buffer solution were mixed $(1: 1 \mathrm{v} / \mathrm{v})$ together and incubated for $1 \mathrm{~h}$ at $30{ }^{\circ} \mathrm{C}$ (Iftikhar et al., 2011). Remaining enzyme activity (residual enzyme activity) was determined by considering the activity of the enzyme without any pre-incubation as $100 \%$. Residual lipase activity was determined by dividing the activity of each sample by the activity found in the control sample and it was expressed in percentage.

$$
\text { Residual activity }=\frac{\text { Activity of sample }\left(\mathrm{U} \mathrm{mL}^{-1}\right) \times 100}{\text { Activity of the control }\left(\mathrm{U} \mathrm{mL}^{-1}\right)}
$$

Impact of temperatures on the activity and stability of partially purified lipase

Lipase assay was carried out at various temperatures $\left(25^{\circ} \mathrm{C}, 30^{\circ} \mathrm{C}, 35^{\circ} \mathrm{C}, 40{ }^{\circ} \mathrm{C}, 50\right.$ ${ }^{\circ} \mathrm{C}$ and $60{ }^{\circ} \mathrm{C}$ ) in order to determine the temperature optima. Temperature stability in above mentioned temperatures was determined by pre-incubating the lipase sample at respective temperature for $1 \mathrm{~h}$ and residual enzyme activity was determined by considering the activity of the enzyme without any pre-incubation as $100 \%$ (Iftikhar et al., 2011; Sarkar and Laha, 2013).

\section{Impact of organic solvents on the activity of purified lipase}

The impact of different organic solvents viz.: methanol, ethanol, acetone, butanol and isopropanol $(10 \% \mathrm{v} / \mathrm{v})$ was investigated on lipase stability by pre-incubation of enzyme fractions and organic solvent $(1: 1 \mathrm{v} / \mathrm{v})$ at 37 ${ }^{\circ} \mathrm{C}$ for $1 \mathrm{~h}$. Thereafter, lipase activity was determined. However, the residual enzyme activity was measured by considering the activity of the enzyme without any organic solvents as 100\% (Kumar et al., 2012). 
Impact of various metal ions on the activity of partially purified lipase

Impact of different metal ions (at a concentration of $1 \mathrm{mM}$ ) on activity of lipase was evaluated by pre-incubating the mixture of enzyme and metal ion solution for $1 \mathrm{~h}$ and then residual lipase activity was determined by considering the activity of the enzyme without any metal ion as $100 \%$. The metal ion studied included sodium chloride, calcium chloride, barium chloride, magnesium sulfate, copper sulfate, ferrous sulfate, manganese chloride and mercury chloride which contributed the metal ions, $\mathrm{Na}^{+}, \mathrm{Ca}^{2+}, \mathrm{Ba}^{2+}, \mathrm{Mg}^{2+}, \mathrm{Cu}^{2+}, \mathrm{Fe}^{2+}, \mathrm{Mn}^{2+}$ and $\mathrm{Hg}^{2+}$, respectively (Ulker et al., 2011).

\section{Results and Discussion}

\section{Impact of temperatures on the activity of partially purified lipase}

In the temperature optima profile (Fig. 1), different behaviour by wild (A. niger LPF-5) and mutant (A. niger HN1) strain was observed. Highest lipase activity by wild $\left(83.42 \pm 0.95 \mathrm{U} \mathrm{mL}^{-1} \mathrm{~min}^{-1}\right)$ and mutant strain $\left(99.51 \pm 1.01 \mathrm{U} \mathrm{mL}^{-1} \mathrm{~min}^{-1}\right)$ was observed at 35 and $30{ }^{\circ} \mathrm{C}$, respectively. For wild strain the activity was highest at $35^{\circ} \mathrm{C}$, followed by $40,30,25,50$ and $60^{\circ} \mathrm{C}$ and for mutant strain the activity was highest at 30 ${ }^{\circ} \mathrm{C}$, followed by $35,25,40,50$ and $60{ }^{\circ} \mathrm{C}$. Activity of lipase by wild strain at $40{ }^{\circ} \mathrm{C}, 50$ ${ }^{\circ} \mathrm{C}$ and $60{ }^{\circ} \mathrm{C}$ was found higher than mutant strain, indicating superior thermostability of lipase of wild strain over mutant strain.

In accordance with the current results, an optimum temperature of $30{ }^{\circ} \mathrm{C}$ for lipase activity was reported by Hosseinpour et al. (2011) for A. niger, Prabhakar et al. (2012) for Rhizopus sp. and Mahmoud et al. (2015) for A. terreus. An optimum temperature of $37{ }^{\circ} \mathrm{C}$ which is very close to temperature optima of our wild strain $\left(35^{\circ} \mathrm{C}\right)$ was reported for activity of $A$. niger lipase by several investigators (Pera et al., 2006; García et al., 2014). Only a few fungal lipases show temperature optima above 40 ${ }^{\circ} \mathrm{C}$ (Razak et al., 1997). However, Niaz et al., (2013) observed highest activity of $A$. niger lipase at $45^{\circ} \mathrm{C}$.

\section{Impact of temperatures on the stability of partially purified lipase}

Lipase from both the wild and mutant strain retained stability within the temperature range of $25-50{ }^{\circ} \mathrm{C}$. Wild strain lipase retained almost $100 \%$ of its activity at $40{ }^{\circ} \mathrm{C}$, while lipase of mutant strain showed highest stability at $35{ }^{\circ} \mathrm{C}$. Lipase of mutant culture retained more than $80 \%$ of its activity within the temperature range of $25-40{ }^{\circ} \mathrm{C}$. Similar to temperature optima pattern, lipase of wild strain was more stable at 40,50 and $60{ }^{\circ} \mathrm{C}$ than mutant strain, indicating its thermostability over mutant strain (Fig. 2). The lipase activity was greatly decreased by increasing the incubation temperature above $50{ }^{\circ} \mathrm{C}$; lipase of mutant strain retaining only $25.43 \%$ of its activity at $60{ }^{\circ} \mathrm{C}$. It might be due to that at elevated temperature, rearrangement of hydrogen and ionic bonds in solvated layer could lead to the conformational changes at the active site of enzyme, therefore activity of enzyme is lost. Ultimately, the enzyme becomes denatured.

The present results are in agreement with Maliszewska and Mastelerz (1992) who reported that lipase of Penicillium sp. was most active at $40{ }^{\circ} \mathrm{C}$ but unstable above $50^{\circ} \mathrm{C}$. Petersen and Daniel (2006) also demonstrated higher extracellular lipase stability at $40^{\circ} \mathrm{C}$. Adham and Ahmed (2009) noticed that when lipase of $A$. niger was preincubate at $60{ }^{\circ} \mathrm{C}$ for $1 \mathrm{~h}$, the enzyme activity decreased significantly. Sundar and Kumaresapillai (2013) observed that lipase 
of A. niger retained stability up to $40{ }^{\circ} \mathrm{C}$ with maximum stability at $30^{\circ} \mathrm{C}$.

\section{Impact of pH on the activity of partially purified lipase}

Highest lipase activity was obtained for both the wild $\left(102.77 \pm 0.84 \mathrm{U} \mathrm{mL}^{-1} \mathrm{~min}^{-1}\right)$ and mutant strain $\left(123.32 \pm 1.08 \mathrm{U} \mathrm{mL}^{-1} \mathrm{~min}^{-1}\right)$ when the $\mathrm{pH}$ of the reaction mixture was 7.0. For wild strain the lipase activity was highest at $\mathrm{pH} 7.0$, followed by 6.5, 6.0, 7.5, $5.5,5.0,4.0,8.0$ and 9.0, while for the mutant strain the lipase activity was highest at $\mathrm{pH} 7.0$ followed by $6.5,7.5,6.0,5.5,5.0$, 4.0, 8.0 and 9.0 (Fig. 3). The activity of lipase from both the strains was found to be higher in the acidic $\mathrm{pH}$ range (4.0-6.5) than in the alkaline $\mathrm{pH}$ range, which indicates the acidic nature of the lipases.

An optimum $\mathrm{pH}$ of 7.0 as found in the present study for the activity of A. niger lipase was also reported by other investigators (Hosseinpour et al., 2011; Sundar and Kumaresapillai, 2013; García et al., 2014). Other investigators (Falony et al., 2006; Sarkar and Laha, 2013) noticed an optimum $\mathrm{pH}$ of 6.0 for $A$. niger lipase.

\section{Impact of pH on the stability of partially purified lipase}

The lipase was found stable within the $\mathrm{pH}$ range of 4.0-7.5 with maximum stability at $\mathrm{pH} 6.5$ (Fig. 4). Stability of lipase was higher in the acidic $\mathrm{pH}$ range than in the alkaline, which shows the acidic behaviour of lipase. At pH 4.0, lipase of both wild and mutant strain retained $37.08 \%$ and $50.39 \%$ activity, respectively. It indicates that lipase obtained from mutant strain is more acid tolerant than wild strain.

Adham and Ahmed (2009) reported that activity of lipase was reduced up to $50 \%$ when pre-incubated at $\mathrm{pH} 8.0$ for $1 \mathrm{~h}$ and Dimitris et al., (1996) revealed that lipase of
A. niger underwent rapid denaturation in alkaline $\mathrm{pH}$ and lost $50 \%$ of its activity when incubated for $1 \mathrm{~h}$. These findings corroborated with the present results.

\section{Impact of organic solvents on the activity of purified lipase}

Of all the tested organic solvents, methanol increased the residual activity up to $110.52 \%$ for wild strain and $128.97 \%$ for mutant strain when compared to $100 \%$ activity of control of respective strains (Fig. 5). Methanol appeared to be the excellent inducer of the activity of lipase, followed by acetone, isopropanol, ethanol and butanol. Partially purified lipase from both the wild and mutant strain of $A$. niger exhibited good tolerance to most of the tested organic solvents but the lipase of the mutant strain was found to be more tolerant towards the organic solvents than the lipase of wild strain. In agreement with the present results, many workers found methanol as an excellent organic solvent for induction of lipolytic activity. Jayaprakash and Ebenezer (2012) reported that lipase of A. japonicus was stable in methanol, acetone, ethanol and hexane with the highest and lowest stability in methanol and butanol, respectively after pre-incubation of $1 \mathrm{~h}$ at $40^{\circ} \mathrm{C}$. Similarly, the lipase of $A$. niger was found stable in methanol, acetone and ethanol, the best solvent being the acetone after preincubation of $1 \mathrm{~h}$ at $37^{\circ} \mathrm{C}$ (Pera et al., 2006).

\section{Impact of metal ions on the activity of partially purified lipase}

Metal ions play an important role in enzymology. Thus, the impact of various metal ions on the stability of lipase was carried out in this study. Among all the metal ions, $\mathrm{Ca}^{2+}$ increased the residual activity up to $104.70 \%$ for wild strain and $111.24 \%$ for mutant strain when compared to $100 \%$ activity of control (Fig. 6). 
Fig.1 Impact of temperatures on the activity of partially purified lipase by wild (LPF-5) and mutant (HN1) strain of $A$. niger

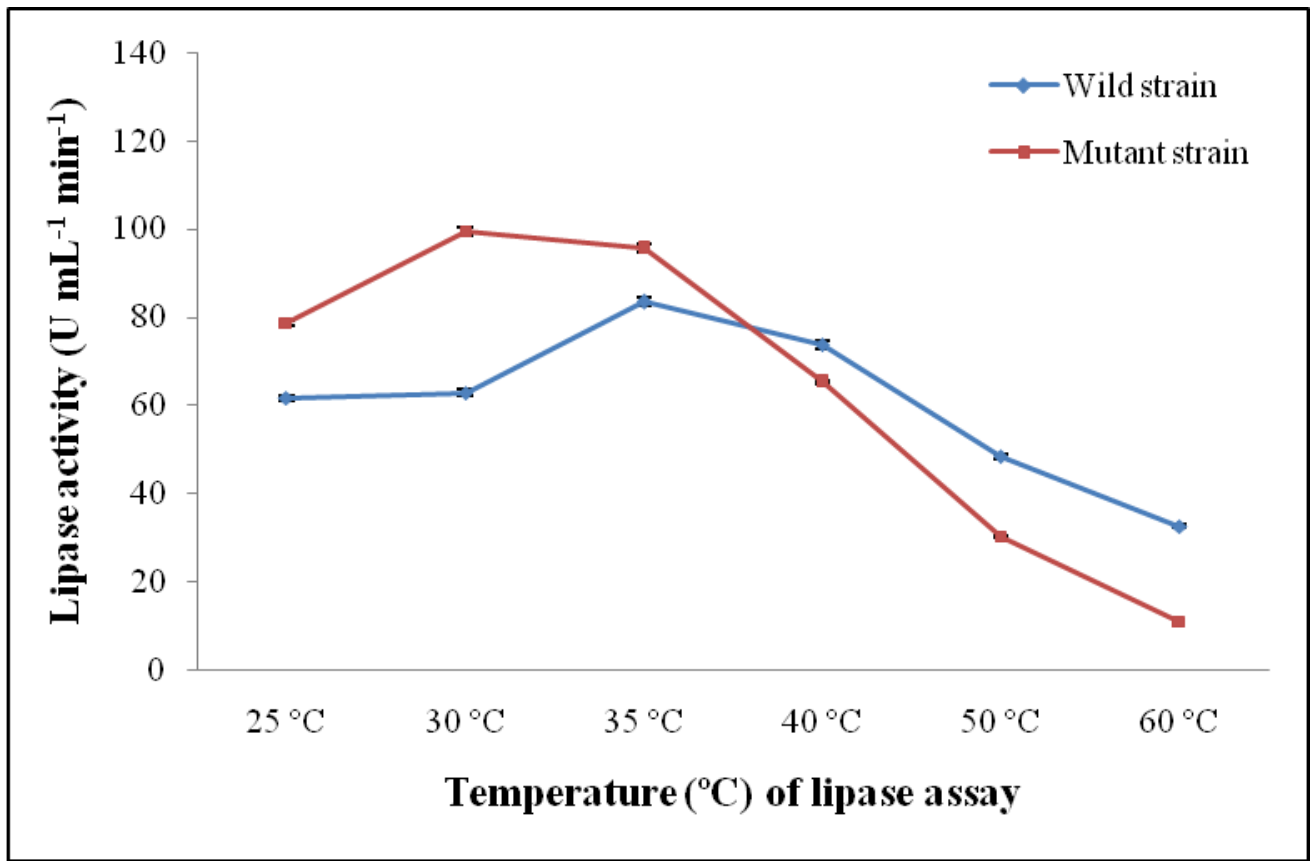

Fig.2 Impact of temperatures on the stability of partially purified lipase by wild (LPF-5) and mutant (HN1) strain of A. niger

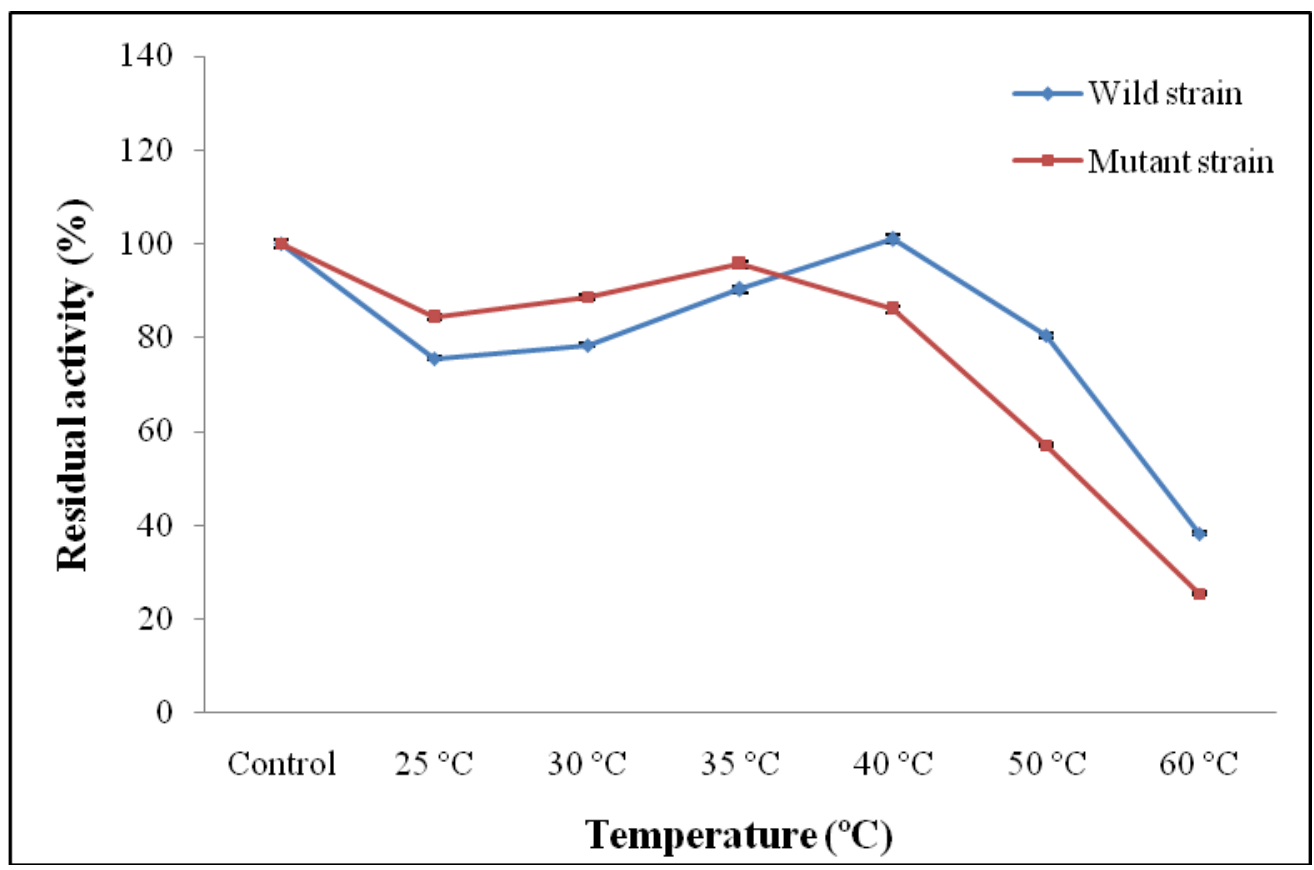


Fig.3 Impact of $\mathrm{pH}$ on the activity of partially purified lipase by wild (LPF-5) and mutant (HN1) strain of A. niger

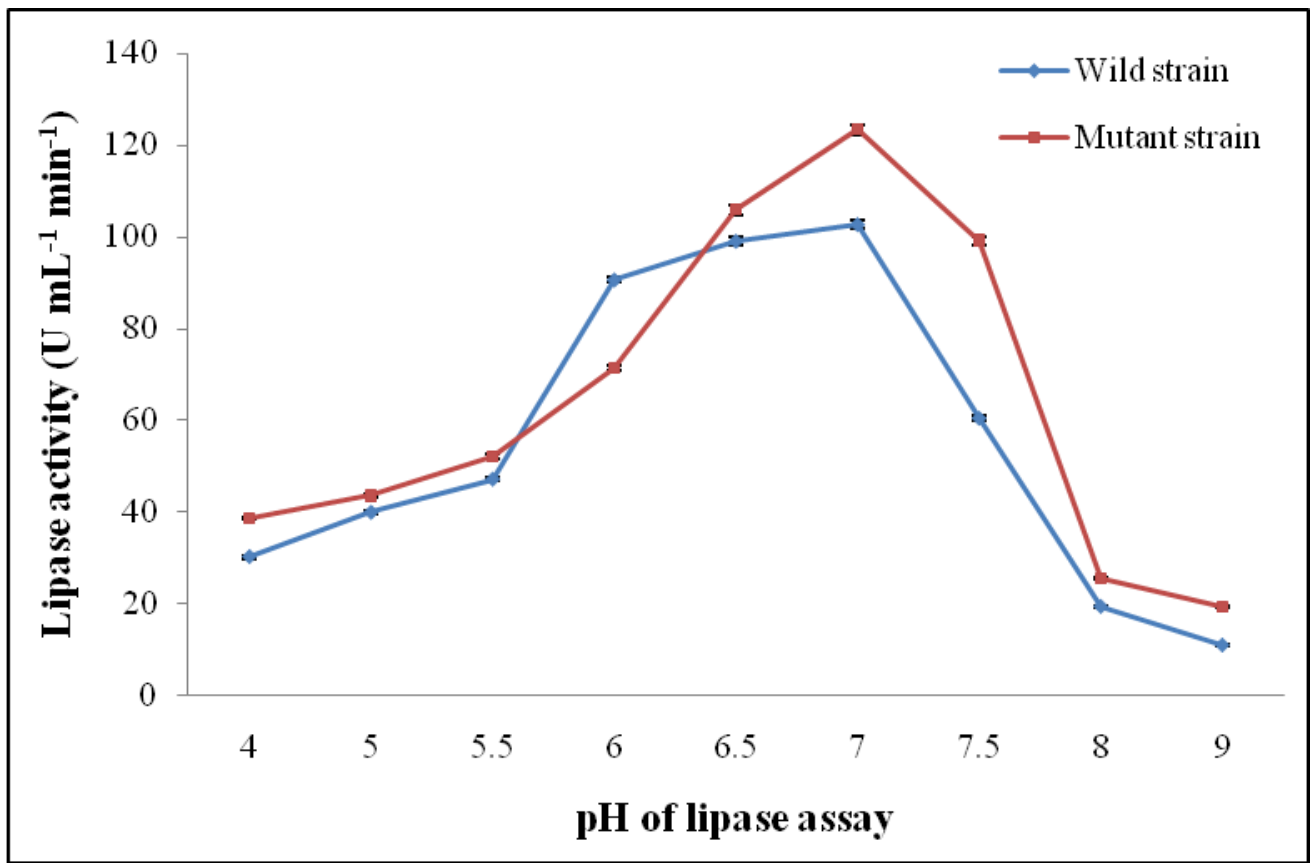

Fig.4 Impact of pH on the stability of partially purified lipase by wild (LPF-5) and mutant (HN1) strain of $A$. niger.

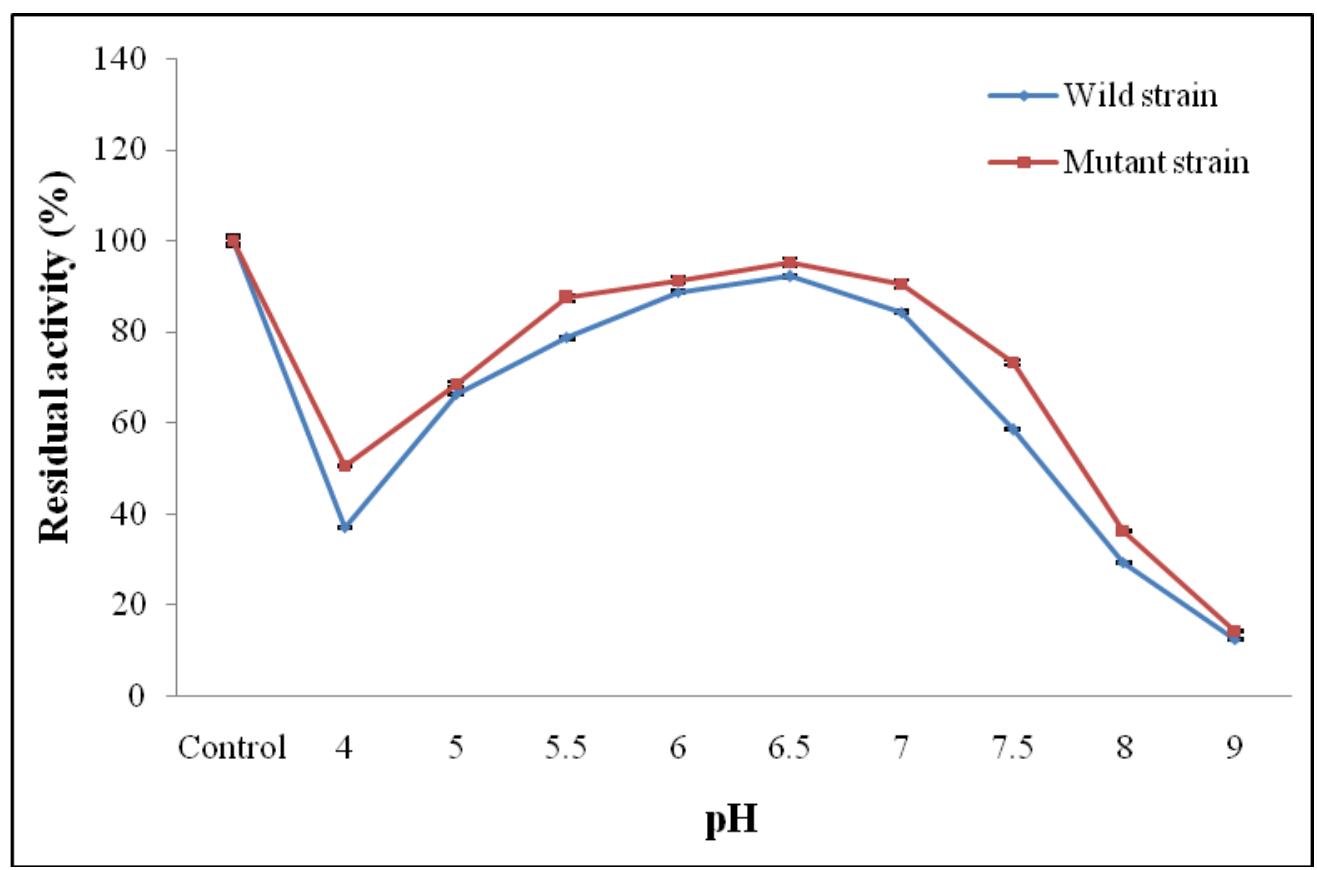


Fig.5 Impact of organic solvents on the stability of partially purified lipase by wild (LPF-5) and mutant (HN1) strain of $A$. niger.

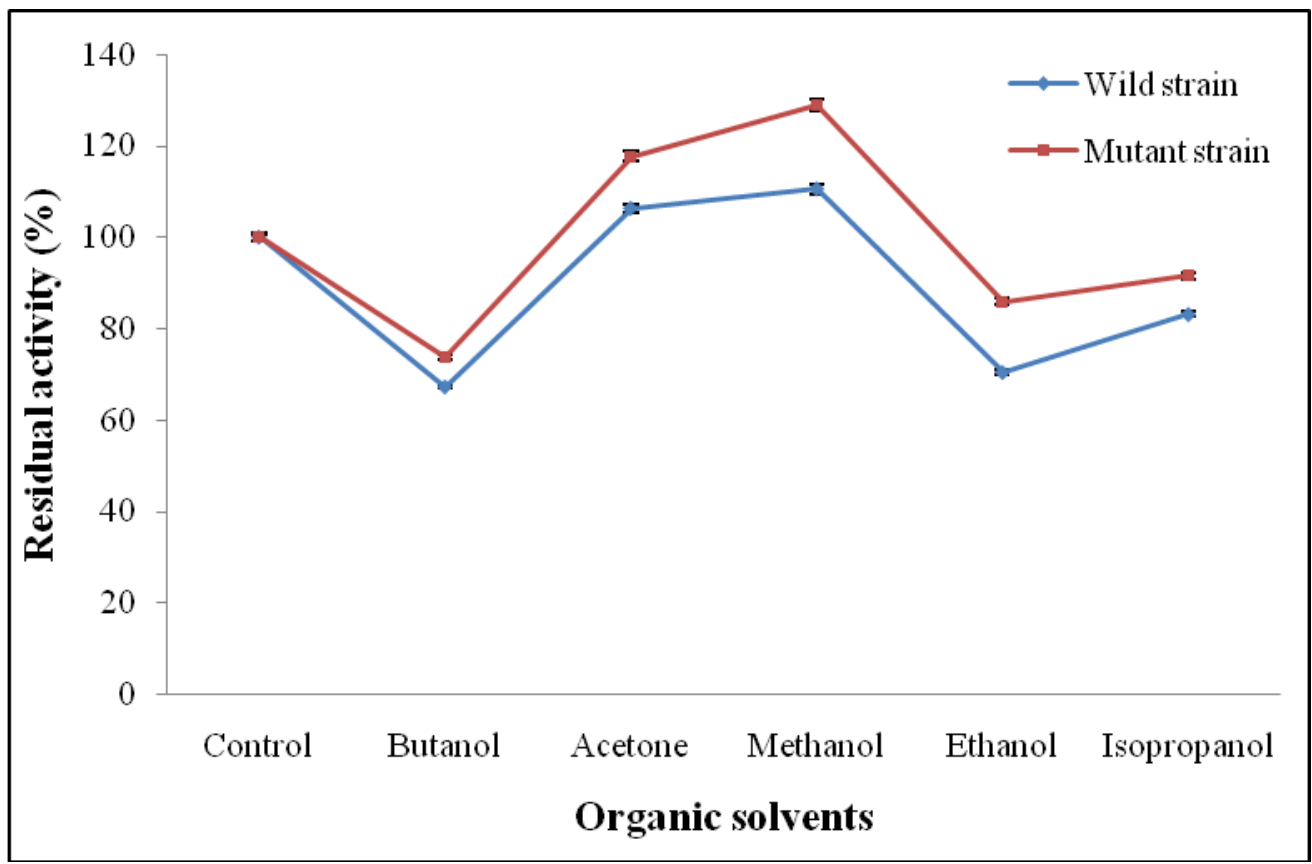

Fig.6 Impact of metal ions on the stability of partially purified lipase by wild (LPF-5) and mutant (HN1) strain of A. niger.

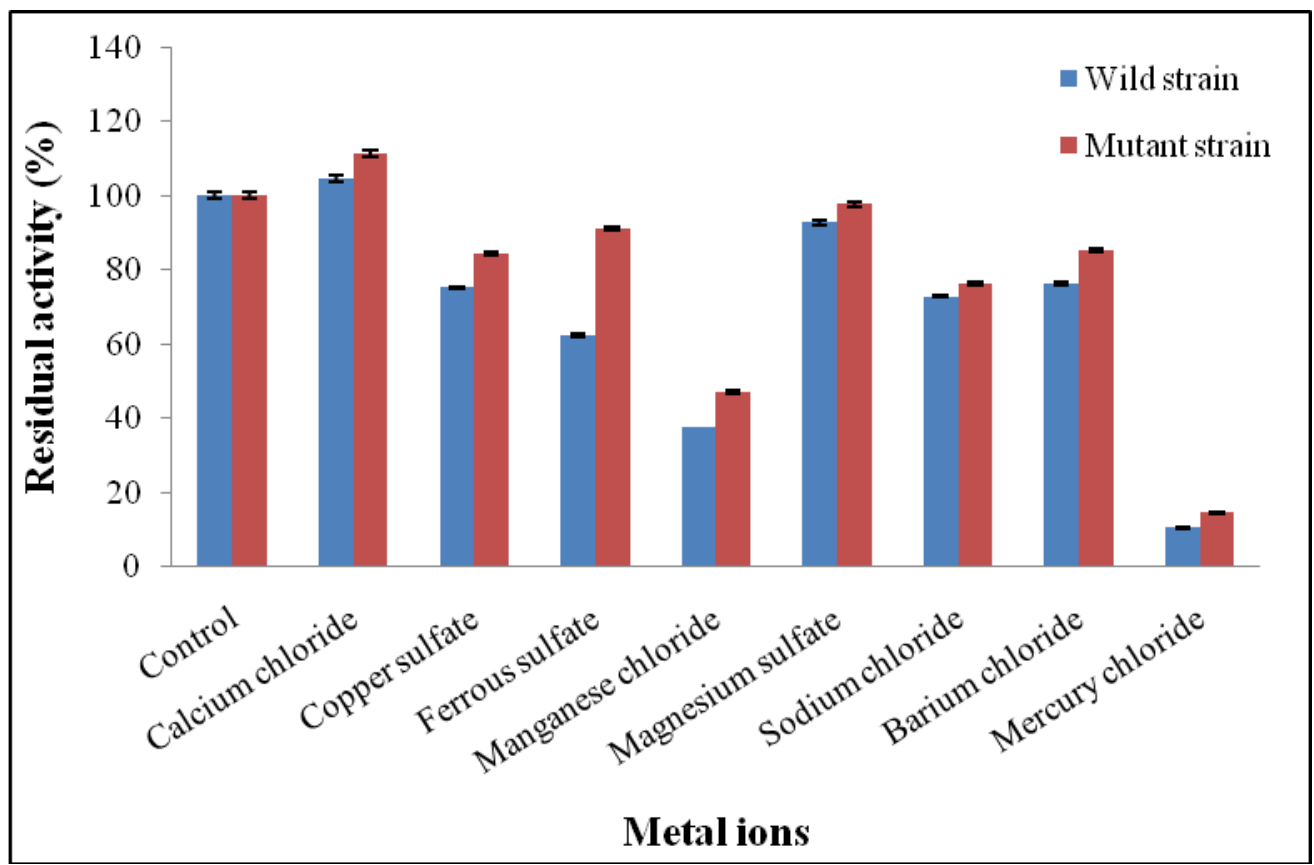

The present findings suggest that stimulatory effect of calcium is due to that $\mathrm{Ca}^{2+}$ ions bind with enzyme and alter the conformation of enzyme. Now enzyme with modified conformation exhibit greater stability and activity. $\mathrm{Ca}^{2+}$ ions appeared to 
be the excellent inducer of activity of lipase, followed by $\mathrm{Mg}^{2+}, \mathrm{Fe}^{2+}, \mathrm{Ba}^{2+}, \mathrm{Cu}^{2+}, \mathrm{Na}^{+}$, $\mathrm{Mn}^{2+}$ and $\mathrm{Hg}^{2+}$. Stability of lipase was found with all metal ions except $\mathrm{Hg}^{2+}$. The residual activity was reached to minimum after preincubation with $\mathrm{Hg}^{2+}$.

Adham and Ahmed (2009) reported that $\mathrm{Ca}^{2+}$ increases the activity of $A$. niger lipase up to $170 \%$, while $\mathrm{Hg}^{2+}$ and $\mathrm{K}^{+}$decreases the residual activity of lipase up to $18 \%$ and $22 \%$, respectively as compared to the $100 \%$ activity of control, which matches to the present results. Stimulatory effect of $\mathrm{Ca}^{2+}$ on lipase activity after $1 \mathrm{~h}$ pre-incubation was also reported by Hosseinpour et al., (2011) for A. niger and Das et al., (2016) for A. tamarii JGIF06.

\section{Acknowledgments}

The authors are grateful to Professor Aditya Shastri, Vice-Chancellor, Banasthali University, Rajasthan for providing necessary research facilities.

\section{References}

Adham, N.Z. and Ahmed, E.M. 2009. Extracellular lipase of Aspergillus niger NRRL3; production, partial purification and properties. Indian J. Microbiol., 49(1): 77-83.

Cai-hong, W., Run-fang, G., Hong-wei, Y. and Ying-min, J. 2008. Cloning and Sequence Analysis of a Novel ColdAdapted Lipase Gene from Strain lip35 (Pseudomonas sp.). Agr. Sci. China, 7(10): 1216-1221.

Das, A., Shivakumar, S., Bhattacharya, S., Shakya, S. and Swathi, S.S. 2016. Purification and characterization of a surfactant-compatible lipase from Aspergillus tamarii JGIF06 exhibiting energy-efficient removal of oil stains from polycotton fabric. Biotech, 6(2): 18.
Dimitris, G., Hatzinikikolaou, M.J.B., Christakopoulos, P., Kekos, D., Kolisis, N.F. and Fountoukidis, G. 1996. Production and partial characterization of extracellular lipase from Aspergillus niger. Biotechnol. Lett., 18(5): 547-552.

Falony, G., Armas, J.C., Mendoza, J.C.D. and Hernandez, J.L.M. 2006. Production of Extracellular Lipase from Aspergillus niger by Solid-State Fermentation. Food Technol. Biotechnol., 44(2): 235-240.

García, S.H., Maria, I.G.G. and Carmona, F.G. 2014. Purification, Immobilization and Characterization of Lipase Isoenzyme from Aspergillus niger with $\mathrm{C} 8$ Magnetic Particles. Adv. Biosci. Biotechnol., 5(7): 633-641.

Hasan, F., Shah, A. and Hameed, A. 2009. Methods for detection and characterization of lipases: A comprehensive review. Biotechnol. Adv., 27(6): 782-798.

Hosseinpour, M.N., Najafpour, G.D., Younesi, H. and Khorrami, M. 2011. Submerged culture studies for lipase production by Aspergillus niger NCIM 584 on soya flour. Middle East J. Sci. Res., 7(3): 362-366.

Iftikhar, T., Niaz, M., Jabeen, R. and Haq, I.U. 2011. Purification and characterization of extracellular lipase. Pak. J. Bot., 43(3): 1541-1545.

Jayaprakash, A. and Ebenezer, P. 2012. Purification and characterization of Aspergillus japonicus lipase from a pig fat production medium. J. Acad. Indus. Res., 1(1): 1-7.

Kumar, A.P., Kumar, K.J. and Narasimha, G. 2012. Isolation of Lipase Producing Fungi from Groundnut Oil Mill Effluent Soil Site at Nandyal. Int. J. Pharma Bio Sci., 3(4): 275-280.

Mahmoud, G.A., Koutb, M.M.M., Morsy, F.M. and Bagy, M.M.K. 2015. Characterization of lipase enzyme produced by hydrocarbons utilizing fungus Aspergillus terreus. Eur. J. Biol. Res., 5(3): 70-77.

Maliszewska, I. and Mastalerz, P. 1992. 
Production and some properties of lipase from Penicillium citrinum. Enzyme Microb. Technol., 14(3): 190193.

Niaz, M., Iftikhar, T. and Zia, M.A. 2013. Effect of Nutritional Factors on Lipase Biosynthesis by Aspergillus niger in Solid State Fermentation. Ext. J. Appl. Sci., 1(1): 9-16.

Pera, L.M., Romero, C.M., Baigori, M.D. and Castro, G.R. 2006. Catalytic Properties of Lipase Extracts from Aspergillus niger. Food Technol. Biotechnol., 44(2): 247-252.

Petersen, M. and Daniel, R. 2006. Purification and characterization of an extracellular lipase from Clostridium tetanomorphum. World J. Microbiol. Biotechnol., 22(5): 431-435.

Prabhakar, T., Praveen Kumar, B., Prasad Rao, V. and Venkateswar, S. 2012. Biochemical characterization of an extracellular lipase from new strain of Rhizopus sp. isolated from oil contaminated soil. Int. J. Pl. An. and Env. Sci., 2(3): 41-45.

Ray, A. 2012. Application of Lipase in Industry. Asian J. Pharma. Technol., 2(2): 33-37.

Razak, C.N.A., Salleh, A.B., Musani, R., Samad, M.Y. and Basri, M. 1997. Some characterisitics of lipases from thermophilic fungi isolated from palm oil mill effluent. J. Mol. Catal. B: Enzym., 3(1-4): 153-159.

Sarkar, D. and Laha, S. 2013. Optimization of extracellular lipase enzyme production from Aspergillus niger by submerged and solid state fermentation process. Int. J. Pharma Bio Sci., 4(4): 978-985.

Sharma, A.K., Sharma, V., Saxena, J., Chandra, R., Alam, A. and Prakash, A. 2015. Isolation and Screening of Amylolytic Bacteria from Soil. Int. J. Sci. Res. Agr. Sci., 2(7): 159-165.

Sharma, D., Sharma, B. and Shukla, A.K. 2011. Biotechnological Approach of Microbial Lipase: A Review. Biotechnol., 10(1): 23-40.

Sharma, S. and Kanwar, S.S. 2014. Organic solvent tolerant lipases and applications. Sci. World J., 2014: 1-15.

Shukla, B. N. and Desai, P. V. 2016. Isolation, Characterization and Optimization of Lipase Producing Pseudomonas sp. from Oil Contaminated Sites. Int. J. Curr. Microbiol. Appl. Sci., 5(5): 902909.

Sundar, W.A. and Kumaresapillai, N. 2013. Isolation, Purification and Medium Optimization of Lipase Enzyme Producing Strains of Aspergillus niger Isolated from Natural Sources. Int. J. Pharm. Pharm. Sci., 5(2): 321-324.

Ulker, S., Ozel, A., Colak, A. and Karaoglu, S.A. 2011. Isolation, production, and characterization of an extracellular lipase from Trichoderma harzianum isolated from soil . Turkish J. Biol., 35(5): 543-550.

Winkler, U.K. and Stuckmann, M. 1979. Glycogen hyaluronate and some other polysaccharides greatly enhance the formation of exolipase by Serratia marcescens. J. Bacteriol., 138(3): 663670.

\section{How to cite this article:}

Arun Kumar Sharma, Vinay Sharma and Jyoti Saxena. 2016. Characterization of Lipase from Wild (LPF-5) and Mutant (HN1) Strain of Aspergillus niger. Int.J.Curr.Microbiol.App.Sci. 5(11): 681-690. doi: http://dx.doi.org/10.20546/ijcmas.2016.511.079 